\title{
The development of DNA-vaccine against classical swine fever
}

\author{
I. A. Pokholenko, T. O. Ruban, O. M. Sukhorada, O. M. Deriabin', \\ T. G. Tytok, V. A. Kordium
}

Institute of Molecular Biology ad Genetics NAS of Ukraine 150, Zabolotny Str., Kyiv, 03143, Ukraine

${ }^{1}$ Institute of Veterinary Medicine UAAS 30, Donetska Str., Kyiv, 03151, Ukraine

e-mail: iyana50oo@ukr.net

\begin{abstract}
The development of a DNA-vaccine against classical swine fever (CSF) is a perspective direction, because it gives an opportunity to develop a marker vaccine due to use of a part of protective antigen molecule, and to induce effectively both cellular and humoral immune response. In this study a recombinant plasmid, containing the fragment of E2 gene of CFS virus (CSFV) in eukaryotic expression vector, has been developed. It has been demonstrated that the fragment of E2 protein of $\mathrm{CSFV}$ is expressed in $\mathrm{CHO}-\mathrm{K} 1$ cells from the developed recombinant plasmid pTR-BKneo, and we suggest that the protein possesses the post-translational modifications. The data obtained are in favor of the created model DNA-vaccine able to induce humoral immune response to fragment of E2 protein of $C S F V$.
\end{abstract}

Key words: CSFV, DNA-vaccine, E2 glycoprotein of CSFV, immunization, humoral immune response.

Introduction. Classical swine fever (CSF) is a dangerous infectious disease causing significant damage to livestock farming world wide and referred to list $A$ diseases of Office International des Epizooties, OIE, Paris. A considerable problem is the survival after CSF virus of wild pigs population, which is considered to be potential source of the infection.

Nowadays, there are two methods of fighting CSF, namely, i) complete elimination of the infected and potentially infected livestock with the ban on

(C) I. A. POKHOLENKO, T. O. RUBAN, O. M. SUKHORADA, O. M. DERIABIN, T. G. TYTOK V. A. KORDIUM, 2007 vaccination of animals and ii) introduction of inactivated, recombinant, and live vaccine, lapinized and obtained in cell culture. Although both of these methods are widely used, both of them have some disadvantages, among which, in regards to the first one, significant economic losses caused by livestock elimination can be singled out. And one of the main disadvantages of traditional CSF preventive vaccines is their incapability of differentiating postvaccinal and postinfectional immunity. This very question is of great importance as the diseases may cause weakly virulent strains of CSF virus (CSFV), which result in the occurrence of atypical forms of the diseases, immune tolerance, and asymptomatic virus carrying, 
and, therefore, may lead to spreading of the infection to a wide range of animals. In regards to the aforementioned, the problem of development of new types of vaccines and diagnostic systems the application of which will allow serological differentiation of vaccinated animals from those infected with field strains acquired special urgency.

The development of DNA-vaccines against classical swine fever (CSF) is considered to be one of the most perspective vaccinology trends. This direction is based on principally new approach to vaccination which involves introduction of protein encoding DNA directly into the organism instead of protein antigen. DNA vaccines match all basic requirements to vaccines against CSF introduced by controlling EU organizations [1]. Firstly, it is due to the fact that only gene of main protective antigen is introduced to the organism, which makes vaccine strain reversion impossible. Secondly, the manufacturing and storage of vaccines is simplified due to having no need to work with the pathogen and maintaining cold chain, and, thus, the cost of the preparation decreases. It is noteworthy that, similar to the case of recombinant vaccines, it is possible to develop marker vaccine by means of using only a part of gene which encodes target antigen.

Considering the mentioned above the aim of our work was the development of model DNA vaccine which carries protective CSFV antigen, as well as investigation on the possibility of induction of humoral immune response in mice after the immunization with the developed recombinant construction.

Materials and Methods. The following strains of Escherichia coli Sure ${ }^{\circledR}$ (e14 $\left(\right.$ Mcr $\left.^{-}\right) \Delta($ mcrCB-hsd SMR-mrr) 171 endA1 supE44 thi-1 gyrA96 relA1 lac recB recJ sbcC umuC::Tn5 (Kan $\left.{ }^{\prime}\right)$ urvC $\left[F^{\prime}\right.$ proAB lacl $^{4}$ Z $\Delta$ M15 Tn10 (Tet') Amy Cam']) (Stratagene, USA), BL21 (DE3) ( $F^{-}$dmc ompT $h s d S\left(r_{B}^{-} m_{B}^{-}\right)$gal $\lambda$ (DE3)) (Stratagene); the plasmids of $p T R-U F$, kindly granted by S. Zolotukhin (U. F. Gene Therapy Center Vector Core Lab); pET24ap-csfc@rev, received from O. G. Deryabina (unpublished data), $p E G F P-C 1$ received from ClonTech, USA; restriction endonucleases, T4-DNA-ligase obtained from MBI Fermentas, Lithuania, were used in this work. DNA was hydrolyzed in accordance to the manufacturer's recommendations. Re-cloning of DNA fragments was performed according to the methods described in [2]. E. coli cells were transformed with plasmid DNA using calcium chloride method [3]. Plasmid DNA for immunization was isolated from $E$. coli cells (Sure ${ }^{\circledR}$ 2) by the method of alkaline lysis with subsequent deproteinization with phenol and chromophorm as described in [2].

Expression of fragment of E2 CSFV in BL (DE3) cells. Bacterial culture was cultivated on LB nutrition medium (Amersham Biosciences, USA) [2] containing kanamycin in final concentration of $50 \mathrm{Mg} / \mathrm{ml}$. The solution of isopropyl-в-D-thiogalactoside (IPTG, MBI Fermentas) to the final concentration of $1 \mathrm{mM}$ was added to induce synthesis of desired product. The cells were cultivated at $37^{\circ} \mathrm{C}$ to optical density of 2.5 , then the IPTG was added to the medium and the cultivation of producent strain continued at the same temperature for 12 hours.

Electrophoresis of proteins was performed according to Leammli et al. method [8] in 13\% PAAG in the presence of $1 \%$ SDS with subsequent staining with coomassie R-250.

Transfection of CHO-K1 cells (Chinese hamster ovary cells). CHO-K1 culture was obtained from Russian cell culture collection (Saint Petersburg). The cells belonging to this line are epithelial-like. Karyotype: $2 \mathrm{n}=22$ with variability in the range between 16-22 chromosomes. Modal number of chromosomes is 20 . Number of markers at differential staining is 12 [4]. CHO-K1 line cells were cultivated on the nutrition medium of the following composition: $90 \%$ of F10 medium (Sigma), 10\% of bovine embryonic serum (Genome, Ukraine), 100 units/ml of penicillin, and $100 \mathrm{Mg} / \mathrm{ml}$ of streptomycin (Kyivmedpreparat, Ukraine). Prior to use, the serum was inactivated by heating at $56-60 \mathrm{EC}$ for $30 \mathrm{~min}$. To subculture the cells, they were taken off the glass with $0.25 \%$ trypsin solution and $0.02 \%$ of Versen solution (Biotestlaboratory, Ukraine) in 1:1 ratio, then the cells were plated in the ratio of $(1: 4)-(1: 15)$. The cells were cultivated at $37{ }^{\circ} \mathrm{C}$ in the atmosphere containing 5\% $\mathrm{CO}_{2}$. Transfection was performed by a chemical method using synthetic polymer - branched polyethyleneimine with molecular weight of $25 \mathrm{kDa}$ (Aldrich, USA) [5]. 
Control cells were transfected with $p E G F P-C 1$ plasmid. In 72 hours the cells were taken off the glass surface, pelleted by centrifugation for $20 \mathrm{~min}$ at 2000 rpm. Supernatant was decanted and the cell pellet was resuspended in $50 \mathrm{Ml}$ of PBS buffer, $\mathrm{pH} 7.4$, and frozen at $-20^{\circ} \mathrm{C}$.

Obtaining of hyperimmune swine serum against E2 $C S F V$. Recombinant E2 of CSFV for immunization was obtained as described in [6]. Healthy non-vaccinated 4-month-old $30 \mathrm{~kg}$ piglet, born from non-vaccinated sow, was immunized twice with two-week interval by recombinant protein E2 CSFV, 3 mg per intramuscular immunization, with adjuvant of montanide ISA-25 (Seppic), 20\% volume. The blood for serum obtaining was collected in two weeks after the second immunization. The serum was obtained using the standard method [7].

Determining expression of E2 CSFV in CHO-K1 cells by immunoblotting. Immunoblotting was performed in accordance to the standard method, described in [8]. Hyperimmune swine serum obtained as earlier described, at working dilution 1:1000, was utilized as the first antibodies, antibodies against swine immunoglobulines (Sigma), conjugated with horse-radish peroxidase, at working dilution 1:400, were chosen to be the second antibodies.

Immunization. 2-2.5-month-old BALB/c line female mice (bred at the Institute of Molecular Biology and Genetics National Academy of Sciences of Ukraine) were used for immunization. Mice were fed with standard food regularly. All manipulations with mice were performed using sedative and anesthetic preparations in accordance to the Regulations on Veterinary. Several groups of mice were intramuscularly injected thrice into quadriceps or biceps with $100 \mathrm{Mg}$ of plasmid DNA dissolved in $150 \mathrm{Ml}$ of saline, immunization interval was 2 weeks. In 10 days after last immunization blood was taken by retroorbital puncture for the preparation of serum.

ELISA. The titre of IgG, specific to fragment of E2, in serum samples was determined by ELISA. Recombinant E2 CSFV was obtained as earlier described in [6]. Antigen in final concentration of 0.01 $\mathrm{mg} / \mathrm{ml}$ in the volume of $100 \mathrm{Mkl}$ was sorbed on polystyrene strips (Titertek, UK) for 18 hours. Later on, antigen surplus was flushed with PBS buffer, $\mathrm{pH}$ 7.4, containing $0.05 \%$ of twin-20 (Amersham Biosciences). The sera and anti-mice conjugate with horse radish peroxidase (BD, Biosciences) were applied in PBS, $\mathrm{pH}$ 7.4 , containing $0.05 \%$ of twin- 20 and $1 \%$ of skim milk in the volume of $100 \mathrm{mkl}$. Sera with antigen were incubated for $60 \mathrm{~min}$ at $37^{\circ} \mathrm{C}$. Flushed thrice, anti-mice conjugate with horse radish peroxidase (BD Biosciences) in the volume of $100 \mathrm{Mkl}$ in the ratio of 1:1000 was applied. The incubation was performed at $37^{\circ} \mathrm{C}$ for $90 \mathrm{~min}$, then the solution was washed five times and the solution of TMB (Sigma) with hydrogen peroxide in final concentration of $0.015 \%$ was applied; the incubation proceeded for $20 \mathrm{~min}$ at $37^{\circ} \mathrm{C}$. The reaction was terminated by $1 \mathrm{~N}$ solution of sulphuric acid and $\mathrm{OD}_{450}$ was measured.

The results were assessed using the Student's test.

Results and Discussion. E2 (gp55) CSFV glycoprotein, which is considered to be the most immunogenic protein of CSFV, was chosen as antigen for development of DNA-vaccine. As it has been shown earlier the immune response to E2 is sufficiently enough to protect the animals from CSFV challenge [10]. This glycoprotein has been used in the series of works dedicated to the development of DNA vaccine against CSF, however, the authors of predominant majority of them used full-size E2, which made it more complicated to create the diagnostic system capable of differentiating the vaccinated animal from the infected one, as it was mentioned before, E2 is considered to be the most immunogenic protein of CSFV [11-13]. And though, in some works [14, 15], E2 fragments were used for development of DNA vaccine and their immunogenicity was revealed, the authors verified only the fragments depleted of signal sequence and transmembrane domain, whereas all antigenic determinants were preserved to be the same as of wild type protein.

According to the structure proposed in [10] E2 CSFV contains four basic antigenic determinants (A, B, $\mathrm{C}$, and D) located on two subunits. Thus, using one part of the molecule, which contains basic protective determinants, it is possible to develop the DNA vaccine and (using the other part of the molecule) the diagnostic system, capable of differentiating postvaccinal and postinfectional immunity at the same time. In our work we used the part of E2 which is encoded by SacI-EcoRI 


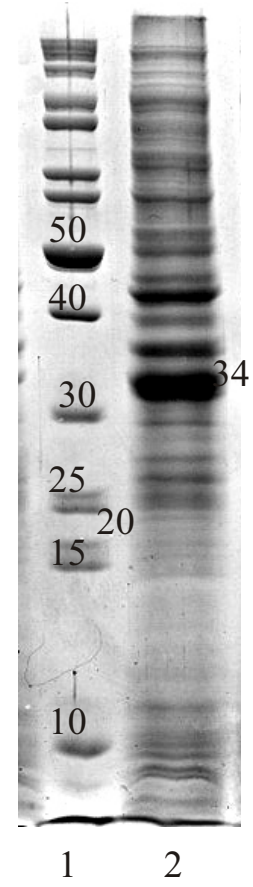

Fig.1 Electrophoregram of sample cells of $E$. coli BL (DE3) containing pET24ap-csfc@rev, cultivated at $37^{\circ} \mathrm{C}$ after induction for 12 hours (2). The sample in the amount equal to 20 Ml of cell suspension ( 1 - marker Page Ruler $^{\mathrm{TM}}$ Protein ladder, MBI Fermentas) was applied on gel.

fragment of gene. This part encodes one antigenic subunit with epitopes A and D. Epitope A is divided into three subdomains $\mathrm{A} 1, \mathrm{~A} 2$, and $\mathrm{A} 3$. Literature data show that antibodies against Al subdomain are considered to be virus neutralizing ones, while A2 subdomain is highly conservative in more than $90 \%$ of CSFV strains. Therefore, the use of this protein for development of DNA vaccine will enable to meet one of the main requirements set for vaccines, i.e. ability to provide the protection of vaccinated specimen from maximally possible number of pathogenic strains. Fragment encoding SacI-EcoRI part of the gene of structural envelope protein E2 of virulent Shi-Min strain was originally cloned by Kirilenko et al. [16]. Shi-Min strain has been used as positive control agent in diagnostics and assessment of immunological features of anti-CSF vaccines in the course of several decades.

The mentioned above E2 fragment, produced in $E$. coli cells, was shown to be capable of causing the immune response in piglets as well as protecting them from lethal infection during the further challenge with highly virulent CSFV Washington strain [6].

pET24ap-csfv@rev plasmid containing SacI-EcoRI fragment of CSFV Shi-Min E2 gene under the

regulation of $\mathrm{T} 7$ promoter was selected as a source of E2 CSFV. However, prior to subcloning, we checked the functionality of target gene by the expression in $E$. coli cells. For this purpose, E. coli cells of BL (DE3) were transformed by plasmid DNA and clones obtained were checked for E2 fragment expression as it was earlier described in Materials and Methods. The suspension of cells obtained after 12-hour induction was analyzed using gel-electrophoresis in polyacrylamide gel in denaturing conditions. Fig.1 presents electrophoregrams which allow making the conclusion that $\mathrm{E} 2$ fragment (molecular weight $34 \mathrm{kDa}$ ) is expressed in E. coli cells.

For re-cloning, the fragment obtained using hydrolysis of pET24ap-csfc@rev by sites of recognition with restriction endonucleases $X b a I$ and $X h o I$ and vector - by XbaI and SalI sites with subsequent ligation and transformation of competent $E$. coli cells strain Sure 2 was used. Hence, recombinant construction pTR-BKneo was obtained (Fig.2). This construction contains the fragment of gene of E2 glycoprotein of CSFV, which is placed under the regulation of strong non-tissue specific enhancer/promoter of the immediate early genes of human cytomegalovirus [17, 18], located between inverted terminal repeats of human adeno-associated virus, at the presence of which, (as shown in $[19,20]$ ), significant increase of humoral and cellular immune response to DNA vaccination is observed.

To check the expression of E2 CSFV in culture of eukaryotic cells, the cells of CHO-K1 line have been selected. Transfection of cells was performed using branched polyethyleneimine (molecular weight of 25 $\mathrm{kDa}$ ) as described in Materials and Methods.

Control cells were transfected with $p E G F P-C 1$. On the third day after transfection the cells were taken off the glass surface using the trypsin solution and Versen's solution, and then the cells were concentrated by centrifugation. E2 expression level was determined using the method of immunoblotting. Swine hyperimmune serum obtained after vaccination using recombinant anti-CSF vaccine was used as the first antibodies. Lysate of CHO-K1 line cells transfected with $p E G F P-C l$ plasmid was selected to be the negative control while recombinant fragment of E2 


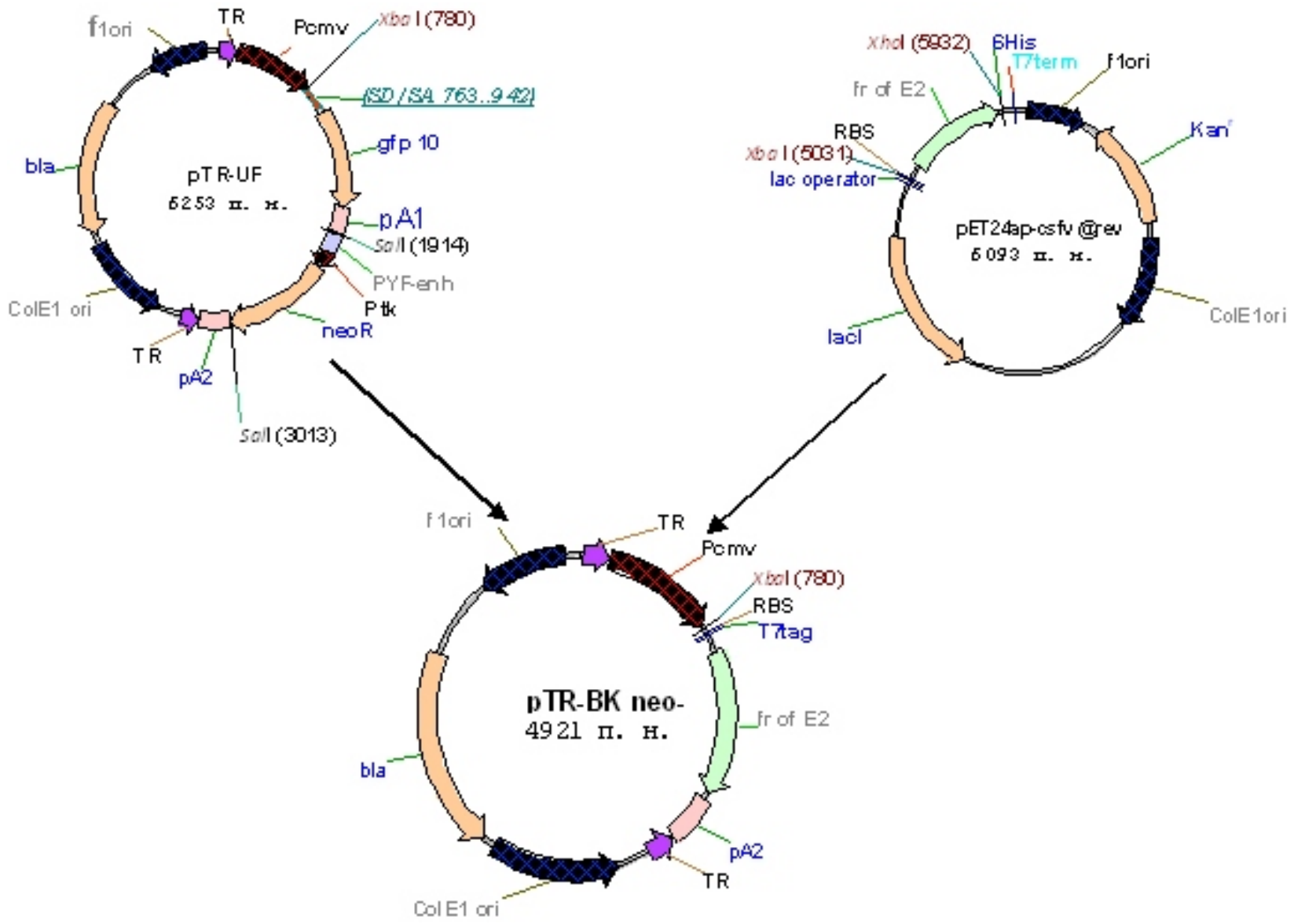

Fig.2 Scheme of recombinant plasmid $p T R-B K n e o^{-}$construction. $T R$ - inverted terminal repeats AAV-2; $P c m v-$ enhancer/promoter of the immediate early genes of human cytomegalovirus; fr of E2 - SacI-EcoRI fragment of E2 of CSFV; $p A 1$ and $p A 2$ - signals of polyadenylation; bla- 6 -lactamase gene; $g f p 10$

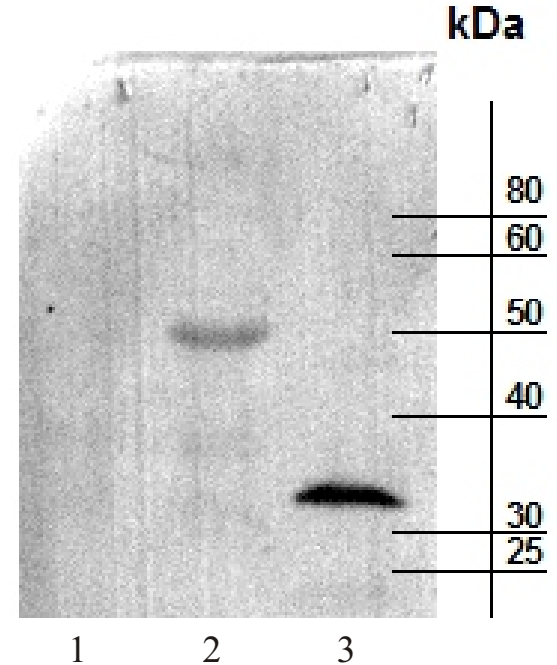

Fig.3 Determination of transient expression of E2 fragment of CSFV in cells of CHO-K1 line using the method of immunoblotting: 1 - lysate of control cells transfected with $p E G F P-C 1 ; 2$ - lysate of cells transfected with $p$ TR-BKneo ; 3 - recombinant E2 CSFV produced in E. coli cells. obtained in E. coli cells was selected to be the positive one.

As a result of the investigation conducted the cells transfected with $p T R-B K n e o^{-}$were shown to express the fragment of E2 (Fig.3). However, the analysis performed revealed that molecular weight of the detected protein equals $50 \mathrm{kDa}$, while molecular weight of the protein obtained in $E$. coli cells equals $34 \mathrm{kDa}$ only. The difference in molecular weight may be explained by the fact that the protein is glycolized in CHO-K1 line cells, and, in accordance to literature data, the part which is encoded by SacI-EcoRI fragment of E2 contains all five glycosylation sites [10] present in E2 molecule. It is noteworthy that, though, calculated molecular weight of full-size E2 is $42 \mathrm{kDa}$, mature glycoproteid has the molecular weight value of $55 \mathrm{kDa}$ [21]. Thus, the value of $14 \mathrm{kDa}$ is received due 


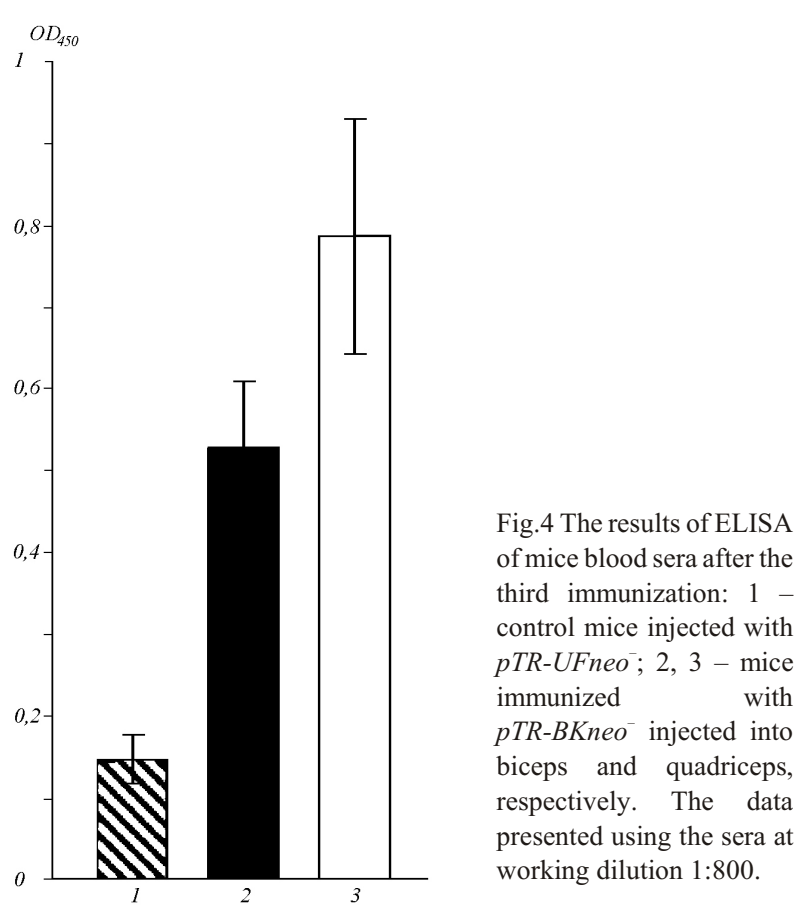

to glycosylation. Therefore, molecular weight of the fragment used in our work is $48 \mathrm{kDa}$. The difference in $2 \mathrm{kDa}$ may be the reason of both separative capacity of gel and the difference in glycosylation between swine cells and the cells of CHO-K1 line (Chinese hamster ovary cells).

Therefore, the research performed demonstrated that E2 fragment of CSFV is expressed in CHO-K1 line cells of recombinant construction of pTR-BKneoBasing on the data obtained, the supposition can be made that post-translation modification, i.e. glycosylation takes place.

In order to verify the possibility of induction of humoral immune response during vaccination using the developed DNA vaccine the mice were immunized according to the scheme described in Materials and Methods. As our previous work [22] indicated that the effectiveness of induction of humoral immune response to the DNA vaccine depends on the site of injection, plasmid DNA was injected into biceps or quadriceps. Control group mice were introduced with initial vector pTR-UFneo, and the experimental group was introduced with recombinant construction pTR-BKneo- The presence of E2 specific antibodies was determined using ELISA in 10 days after last (the $3^{\text {rd }}$ ) immunization. Results of the analysis performed are presented in Fig.4. As it is evident, immunization with pTR-BKneo resulted in induction of humoral immune response to E2 regardless of the site of injection $(p<0.01)$, while induction effectiveness is statistically proven not to be different $(p<0.05)$. Contrary to this data, our previous work [22] where the model antigen was chosen to be $\beta$-galactosidase of $E$. coli demonstrated that effectiveness of induction of humoral immune response depends on the site of injection of plasmid DNA preparation. Hence, the injection into biceps induced the production of $\beta$-galactosidase specific antibodies, and none in the case of quadriceps injection. We supposed that the difference discovered may be explained by the difference of antigens, as well as by different effectiveness of transfection of myocytes by different plasmids. In the latter case, a valuable role can be given to the size of introduced vector construction. It is also important to notice that modeled DNA vaccine which carries gene of $\beta$-galactosidase of $E$. coli is almost 2500 b.p. larger than $p T R-B K n e o^{-}$.

The literature data present indicate that the size of the molecule is significant at the penetration of DNA molecule through the cytoplasmic membrane of myocytes [23]. One does not need to cast away the possibility of hydrostatic pressure, as in the case of biceps injection, the pressure value is higher than in the case of quadriceps injection. The increase in pressure may lead to the formation of small temporal pores in cell membranes [24], through which plasmid DNA will pass, which in its turn increases the effectiveness of transfection of cells and this effectiveness will increase due to decrease in molecule size.

Conclusions. The work presented shows the development of recombinant construction which carries SacI-EcoRI fragment of E2 CSFV as a part of eukaryotic expression cassette, it was also shown that after the introduction of the developed recombinant plasmid pTR-BKneo into CHO-K1 line cells the fragment of E2 of CSFV is expressed. We made the supposition that the post translational modification of the latter takes place. The developed DNA vaccine is capable of inducing the production of antibodies specific to fragment of E2 glycoprotein of CSFV in mice, and the level of induction of humoral immune 
response does not vary significantly depending on the site of intramuscular injection.

Я. А. Похоленко, Т. А. Рубан, Е. М. Сухорада, О. Н. Дерябин, Т. Г. Титок, B. А. Кордюм

Создание ДНК-вакцины против классической чумы свиней

Резюме

Разработка ДНК-вакиины против классической чумы свиней (КЧС) представляет собой перспективное направление, поскольку именно в этом случае возможно создать маркированную вакиину благодаря использованию только части молекулы протективного антигена и обеспечить эффективную индукииио как гуморального, так и клеточного иммунного ответа. В ходе проведенного исследования создана рекомбинантная конструкиия, несущая фрагмент гена Е2 ВКЧС в составе эукариотной экспрессионной кассеть, и показано, что с полученной рекомбинантной плазмиды рTR-ВКпео в клетках линии НО-К1 экспрессируется фрагмент Е2 ВКЧС. Сделано предположение о том, что проходит посттрансляционная модификация этого фрагмента. Созданная модельная ДНК-вакцина способна индуцировать продукиию специфических к фрагменту Е2 ВКЧС антител у мылшей.

Ключевые слова: вирус классической чумы свиней (ВКЧС), ДНК-вакиина, Е2 гликопротеид ВКЧС, иммунизачия, гуморальный иммунный ответ.

\section{REFERENCES}

1. Dong $X$. N., Chen Y.-H. Marker vaccine strategies and candidate CSFV marker vaccines // Vaccine.-2006.-25.-P. 205-230.

2. Sambrook J., Fritsch E. E., Maniatis T. Molecular cloning.-New York: Cold Spring Harbor Lab. press, 1989.-625 p.

3. Current protocols in molecular biology / Eds F. M. Ausubel.-New York: J. Willey \& Sons, 1997.-Vol. 1.-P. 1.8.1.-1.8.3.

4. Catalogue Russian cell culture collection (RCCC).-St. Petersburg; OMSK, 1999.-33 p.

5. Топорова Е. К., Новикова С. Н., Лихачева Л. И., Сухорада Е. М., Рубан Т. А., Козел Ю. Н., Иродов Д. М., Кордюм В. А. Невирусная доставка гена ароА1 человека в клетках млекопитающих in vitro и in vivo // Біополімери і клітина.-2004.-20, № 1-2.-С. 25-32.

6. Дерябін О. М., Дерябіна О. Г., Кулініч Р. М., Рєзнік В. С. Протективні властивості рекомбінантного білка Е2 вірусу класичної чуми свиней, експресованого в E. coli // Bicн. Білоцерківськ. держ. аграр. ун-ту.-2005.-Вип. 31.-С. 151-158.

7. Методы исследований в иммунологии / Под ред. И. Лефковитса, Б. Перниса.-М.: Мир, 1981.-Ч. 1.-486 с.

8. Bollag D. M., Rozycki D. M., Edelstein S. J. Protein methods.-New York, 1996.-415 p.

9. Фишер Р. А. Статистические методы для исследователей.-М.: Госстатиздат, 1958.-268 c.

10. van Rijn P. A., Miedema G. K. W., Wensvoort G., van Gennip H. G. P., Moormann R. J. M. Antigenic structure of envelope glycoprotein E1 of hog cholera virus // J. Virol.-1994.-68.-P. 3934-3942.

11. Andrew M. E., Morrissy C. J., Lenghaus C., Oke P. G., Sproat K. W., Hodgson A. L. M., Johnson M. A., Coupar B. E. H. Protection of pigs against classical swine fever with DNA-delivered gp55 // Vaccine.-2000.-18.-P. 1932-1938.
12. Hammond J. M., Jansen E. S., Morrissy C. J., Goff W. V., Meehan C. G., Williamson M. M., Lenghaus C., Sproat K. W., Andrew M. E., Coupar B. E. H., Johnson M. A. A prime-boost vaccination strategy using naked DNA followed by recombinant porcine adenovirus protects pigs from classical swine // Vet. Microbiol.-2001.-80.-P. $101-119$.

13. Wienhold D., Armengol E., Maroquardt A., Maroquardt C., Voigt H., Buttner M., Saalmuller A., Pfaff E. Immunomodulatory effect of plasmids co-expressing cytokines in classical swine fever virus subunit gp55/E2-DNA vaccination // Vet. Res.-2005.-36.-P. 571-587.

14. Makowska-Daniel I., Collins R. A., Pejsak Z. Evaluation of genetic vaccine against classical swine fever // Vaccine.-2001.-19.-P. $2480-2484$.

15. Yu X., Tu C., Li H., Hu R., Chen C., Li Z., Zhang M., Yin Z. DNA-mediated protection against classical swine fever virus // Vaccine.-2001.-19.-P. 1520-1525.

16. Кириленко С. Д., Дерябін О. М., Кириленко О. Л., Дерябіна О. Г., Бусол В. О. Клонування та надекспресія гена структурного білка Е1 штама Ші-Минь вірусу класичної чуми свиней в Escherichia coli // Биополимеры и клетка.-1996.-12, № 5.-С. 93-99.

17. Boshart M., Weber F., Jahn G., Dorsch-Hasler K., Fleckenstein B., Schaffner $W$. A very strong enhancer is located upstream of an immediate early gene of human cytomegalovirus // Cell.-1985.-41.-P. 521-530.

18. Foecking M. K., Hofstetter $H$. Powerful and versatile enhancer-promoter unit for mammalian expression vectors // Gene.-1986.-45.-P. 101-105.

19. Xin K. Q., Ooki T., Jounai N., Mizukami H., Hamajima K., Kojima Y., Ohba K., Toda Y., Hirai S., Klinman D. M., Ozawa K., Okuda K. A DNA vaccine containing inverted terminal repeats from adeno-associated virus increases immunity to HIV // J. Gene Med.-2003.-5.-P. 438-445.

20. Chikhlikar P., de Arruda B. L., Agrawal S., Byrne B., Guggino W., August J. T., Marques E. T. Inverted terminal repeat sequences of adeno-assosiated virus enhance the antibody and $\mathrm{CD} 8^{+}$responses to a HIV-1 p55Gag/LAMP DNA vaccine chimera // Virology.-2004.-323.-P. 220-232.

21. Rumenapf T., Unger G., Strauss J. H., Thiel H.-J. Processing of the envelop glycoproteins of Pestiviruses // J. Virol.-1993.-67.-P. 3288-3294.

22. Похоленко Я. О., Титок Т. Г., Сухорада О. М., Рубан Т. А. Конструювання та дослідження модельної ДНК-вакцини // Біополімери і клітина.-2005.-21, № 3.-С. 270-274.

23. Wolff J. A., Dowty M. E., Jiao S., Repetto G., Begr R. K., Ludtke J. J., Williams P., Slautterback D. B. Expression of naked plasmids by cultured myotubes and entry of plasmids into $\mathrm{T}$ tubules and caveolae of mammalian skeletal muscle // J. Cell Sci.-1992.-103.-P. 1249-1259.

24. Budker V., Budker T., Zhang G., Subbotin V., Loomis A., Wolff J. A. Hypothesis: naked plasmid DNA is taken up by cells in vivo by a receptor-mediated process // J. Gene Med.-2000.-2.-P. 76-88.

УдК 77.21+577.27:615.375:578.833 